
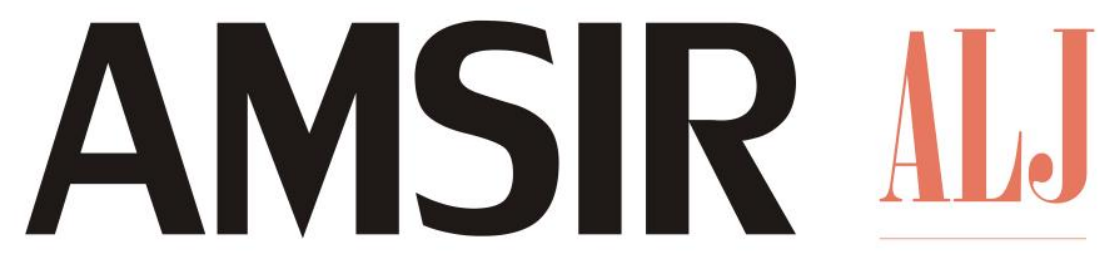

Volume 2

Issue 2

April, 2021

\title{
Legislation Policy to the Elimination of Minimal Capital Legal Entities for Limited Liability Companies
}

\author{
Muhammad Hatta Roma ${ }^{1}$, Nurul Miqat ${ }^{2}$, Andi Intan Purnamasari ${ }^{3}$, \\ Adiesty Septhiany Prihatiningsih Syamsuddin ${ }^{4}$, Manga Patila ${ }^{5}$
}

\section{ARTICLE INFO}

\section{Keywords: \\ Legislation Policy; Capital \\ Write-off; MSME \\ Development; Regional Economic \\ Improvement.}

How to cite:

Roma, Muhammad Hatta., Miqat, Nurul., Purnamasari, Andi Intan., Syamsuddin, Adiesty Septhiany

Prihatiningsih., and Patila, Manga. (2021). Legislation Policy to the Elimination of Minimal Capital Legal Entities for Limited Liability Companies. Amsir Law Journal, 2(2), 59-68.

DOI:

10.36746/alj.v2i2.39

\section{ABSTRACT}

The purpose of this study is to analyze the factors that binder the implementation of government policies against the elimination of minimal capital of legal entities as an effort to develop MSME to improve the regional economy in Palu of Central Sulawesi. This research was an empirical research method using a qualitative descriptive approach. The results showed the factors inhibiting the implementation of government policy on the elimination of minimal capital of legal entity making is the lack of information about Government Regulation Number 29 of 2016 concerning Changes in The Basic Capital of The Establishment of Limited Liability Companies, Constraints on the requirements of making Limited Liability Companies both due to large capital constraints for the manufacture of Limited Liability Companies and Due to Administrative System Constraints that are quite difficult, and the latter is the Orientation of Individualist Thinking.

\section{Introduction}

The national economy is based on economic democracy with the togetherness principles, equitable efficiency, environmental insight, independence, maintaining the balance and integrity of the national economy. Thus one of the considerations of Law Number 40 of 2007 concerning Limited Liability Companies.

\footnotetext{
1 Faculty of Law in Tadulako University, Palu, Indonesia. E-mail: muhammad.hatta.roma@gmail.com

2 Faculty of Law in Tadulako University, Palu, Indonesia.

3 Faculty of Law in Tadulako University, Palu, Indonesia.

${ }^{4}$ Faculty of Law in Tadulako University, Palu, Indonesia.

${ }^{5}$ Faculty of Law in Tadulako University, Palu, Indonesia.
} 
A business entity in the form of a Limited Liability Company has been regulated separately in the Limited Liability Company Law, for maatschap it is still regulated in Chapter Eight, Part One, Burgerlijk Wetboek's third book with the title about "the company", and Fa and CV is regulated in Chapter Two Wetboek van Koophandel with the title about "firm company and the company by releasing money which is also called a limited partnership."

Juridically, the transitional rules in the 1945 Constitution of the Republic of Indonesia confirm that all existing laws and regulations are still valid as long as a new one has not been implemented according to this constitution. The drafters of the Indonesian constitution are aware of several legal issues that have not been regulated by national legislation, to avoid a legal vacuum, products from the Dutch colonial government are still being applied. With the development of the national economy, the laws and regulations governing business entities outside the Limited Liability Company and still based on colonial legacy needs to be revisited. This review is related not only to the basis of the business entity outside the Limited Liability Company in addition to the philosophical, juridical, and sociological foundations but also the need for a theoretical-practical review of the existence of the business entity so that a study of the benefits and contributions of the existence of a business entity outside can be obtained. Limited Liability Companies for the national economy, especially for Micro, Small and Medium Enterprises (MSME). ${ }^{6}$

One of the efforts to provide support for the development of MSME is to provide benefits in the field of business licensing, but with the existence of district/city regulations that oblige every business to have a Nuisance Permit without clear criteria for the types of businesses that can pose threats, dangers and disturbances to the environment will be an obstacle for MSME. In connection with the enactment of Law Number 20 of 2008 concerning MSME, in which to implement economic democracy, MSME needs to be empowered as an integral part of the people's economy which has strategic roles and potential to realize a more balanced, developing, and just national economic structure.

MSME has been proven to be able to survive amid the threat of the economic crisis. Currently, there are many small and medium enterprises standing in various fields, from culinary to handicrafts. In our country, micro, small and medium enterprises are regulated in Law Number 20 of 2008 concerning MSME. Article 6 paragraphs 2 and 3 reads, small businesses have a net worth of Rp. 50.000.000 to Rp. 500.000.000. Meanwhile, medium enterprises have a net worth of Rp. 500.000 .000 to Rp. 10.000.000.000. With their small size and of course high flexibility, small and medium enterprises have various advantages, especially in terms of formation and operation. Micro small business and the medium has a major contribution to the rolling of the economy of a country, not only because it is the seed that enables the growth of the big business, but also because it provides certain services for the people which big business consider to be less cost-efficient.

Commitment, of course, is not enough to improve MSME. Considering there are several legal provisions that must be met by MSME in developing their business. To get convenience from the government, small and medium enterprises must be incorporated, ideally a Limited Liability Company. To establish a Limited Liability Company, usually small and medium enterprises must have initial guarantee capital. This capital can be a problem in itself, which can be burdensome for start-up small and medium business entrepreneurs. Beginner entrepreneurs will consider that capital is better used as productive

\footnotetext{
${ }^{6}$ H. Budiono. (2015). Kumpulan Tulisan Hukum Perdata Bidang Kenotariatan. Bandung: Citra Aditya Bakti, p. 113.

${ }^{7}$ H. E. Bagijo. (2010). Sistem Pelayanan Perijinan Ho (Hinder Ordonnanntie) untuk Kegiatan Usaha Mikro, Kecil Dan Menengah (UMKM), Perspektif, 15(1): 21.
} 
capital than paid for the conditions for establishing a Limited Liability Company. Meanwhile, if the small and medium enterprises are not in the form of a Limited Liability Company, it will be difficult to apply for credit on behalf of the company because there are no documents. Then, it is also difficult to export the product, except only being a supplier for other company's products.

Government policy on business entity establishment deeds, one of which is the elimination of the minimum capital for the formation of a Limited Liability Company for MSME so that it is easier for business actors to create a Limited Liability Company. If it is already a Limited Liability Company, small and medium enterprises will easily market their products, trusted by the market, even can export products. This will have a positive impact if it is linked to the Asean Economic Community later because more and more small and medium enterprises are trusted by the market. Besides, the policy of eliminating the minimum capital of Limited Liability Companies facilitates the development of MSME into Limited Liability Companies, This certainly can increase government revenue from the tax sector. Based on the background above, so the authors are interested in discussing the factors that hinder the implementation of government policies towards the elimination of minimum capital for the creation of legal entities as an effort to develop MSME to improve the regional economy in Palu, Central Sulawesi.

\section{Method}

This research used empirical research methods used a qualitative descriptive approach. This type of research attempts to describe a real picture of the phenomena that occur in the growth of MSME in Palu. Data Collection Methods Data collection consists of primary and secondary legal materials, where the primary legal materials are based on related Positive Laws and other literature studies.

\section{Discussion and Research Results}

\subsection{Strengths and Weaknesses of Small and Medium Businesses and the Steps of Their Establishment}

Some of the advantages possessed by small and medium enterprises compared to large enterprises among others: ${ }^{8}$

1) Innovations in technology that easily occur in product development;

2) Close humanitarian relationships in small companies;

3) Flexibility and adaptability against rapidly changing market conditions compared to large-scale companies, which are generally bureaucratic; and

4) There are managerial dynamism and the role of entrepreneurship.

Small and medium-sized enterprises are usually managed by a small team, each of whose members has the authority to make decisions. This makes MSME more flexible in their daily operations. The speed at which this business reacts to all changes (for example: shifting consumer tastes, product trends, etc.) high enough, so this small-scale business is more competitive. In the absence of a hierarchy of organization and control in MSME, new products and ideas can be designed, developed, and launched immediately.

Although these brilliant ideas come from the thoughts of employees, not owners, the closeness between them makes them more likely to be heard, accepted, and executed. Most small and medium enterprises do not have special workspaces in office complexes. Some

8 T. S. Partomo dan Abd. Rachman Soejoedono. (2002). Ekonomi Skala Kecil/Menengah \& Koperasi. Jakarta: Ghalia Indonesia, p. 18. 
are run in homes with family members working as workers. This reduces the extra costs in operation. Furthermore, Small and medium enterprises also receive support from the government, non-government organizations, and banks in the form of tax facilities, donations, and grants. This factor has a major influence on financing in the formation and operation of small and medium enterprises, which are not obliged to obtain large quantities of sales to reach the break-even point of their capital. This factor enables Small and medium enterprises to focus on specific product sectors or markets. For example, a home craft business can focus on working on one type and certain craft models and sufficiently serve certain consumer demands to be profitable. This is different from the large-scale handicraft industry, which is required to pay to build rental fees and the salaries of a large number of employees, so they must always be able to sell many craft containers to cover only their monthly operating costs. The above are four strengths of MSME that can be used as a source of motivation and are always maintained by small and medium business managers.

However, from these strengths, MSME also has weaknesses that need to be considered as the object of this research study. Some of these weaknesses are:

1) The Difficulty of Marketing

The results of a cross-country study conducted by James and Akarasanee (1988) in several ASEAN countries concluded that one of the aspects related to common marketing problems by MSME entrepreneurs is competitive pressures, both in the domestic market of similar products, made by large and import entrepreneurs, as well as in the export market.

2) Limitations of Financial

MSME in Indonesia faces two main problems in the financial aspect, namely: capital (both initial capital and working capital) and long-term finance for investment which is necessary for long-term output growth.

3) Limited Human Resources

Limited human resources is also a serious obstacle for small and medium enterprises in Indonesia, especially in the aspects of entrepreneurship, management, production engineering, product development, quality control, accounting, machinery, organization, data processing, marketing engineering, and market research. All of these skills are needed to maintain or improve product quality, increase efficiency and productivity in production, expand market share and penetrate new markets.

4) Raw Material Problems

Limitations of raw materials and other inputs also often become a serious problem for output growth or continuity of production for small and medium businesses in Indonesia, especially during the crisis period, many small and medium enterprises centers such as shoes and textile products experienced difficulties in obtaining raw materials or other inputs because their prices in rupiah became very expensive due to the depreciation of the exchange rate against the US dollar.

5) Limitations of Technology

It is different from developed countries, small and medium enterprises in Indonesia generally still use traditional techniques in the form of old machines or manual production tools. This technological backwardness not only lowers the amount of production and efficiency in the production process, but also the low quality of products made and the ability for small and medium enterprises in Indonesia to be able to compete in the global market. Limitations of technology are caused by many

\footnotetext{
${ }_{9}^{9}$ Tulus T. H. Tambunan. (2002). Usaha Kecil dan Menengah Indonesia: Beberapa Isu Penting. Jakarta: Salemba Empat, p. 18.
} 
factors such as limited investment capital to buy new machines, limited information about technological developments, and limited human resources who can operate new machines.

6) Limited Time to Complete Needs

Because of the small number of decision-makers in small and medium enterprises, they are often forced to struggle to meet the basic needs of their business, namely: production, sales, and marketing. This can result in huge schedule pressures, making them unable to focus on solving problems one by one. This kind of pressure can appear suddenly when their business gets a large number of orders, or several orders are entered at almost the same time. It will be even more awesome if one day a large business institution feels threatened and starts launching unfair attacks to get rid of its potential competitors.

7) Strict Control Over Budgets and Financing

Small scale enterprises generally have a small budget as a result, he was often forced to divide funds to finance various needs as efficiently as possible. The inability to raise more capital also forces small and medium enterprises to implement strict austerity policies, especially to prevent the slightest shortfall in operational financing. Lack of operational financing that is not prevented can lead to bankruptcy because the capacity of MSME to pay debts is usually almost non-existent.

8) Lack of Experts

Small and medium enterprises are usually unable to pay the services of experts to complete certain jobs. This is a very serious weakness of small and medium enterprises. Especially when compared to large business institutions that can employ many experts. The quality of goods or services that can be produced without experts is likely to be below a certain standard. As a result, the competitiveness of these small-scale enterprises in a broad market can be very small.

Some of the weaknesses of MSME above certainly consider so that the development of MSME are not just a discourse. Besides, data on MSME is not insignificant. For example, the number of MSME in Central Sulawesi Province currently has reached 702,719 units. Data on MSME until 2015 consisted of 114,188 medium enterprises, 176,231 small enterprises, and 412,300 micro-enterprises. According to the Central Sulawesi Provincial Government, MSME is the backbone of the people's economy, therefore the provincial government continues to be committed to fostering them in various aspects, including management, promotion, and marketing, improving product quality, and human resources for business actors and capital. ${ }^{10}$

For the steps in establishing a business, the company must pay attention to the following important points so that later it can be seen what aspects must be prepared in its business planning. The following are steps that should be noted by business actors:

1) Capital preparation to establish a Limited Liability Company

The Limited Liability Company Law is one of the pillars that provide the foundation for the business world and the national economy in facing the development of the world economy is the globalization era. Although there have been various improvements since 2007, there are still problems related to the identity of a Limited Liability Company as a legal entity and other problems related to the process of its establishment. ${ }^{11}$

\footnotetext{
${ }^{10}$ Fauzi. (2016). Sulteng Miliki 702719 UMKM. Available online from: http://mmw.antarasulteng.com [Acessed February 3, 2020].

11 H. Budiyono. (2012). Arah Pengaturan Undang-undang Nomor 40 Tahun 2007 tentang Perseroan Terbatas dalam
} 
According to Law Number 40 of 2007 concerning Limited Liability Companies, the authorized capital of a Limited Liability Company is IDR 50 million with a minimum deposit of $25 \%$ as capital for the Limited Liability Company. The requirements are written in this Law sometimes become obstacles or problems for entrepreneurs who wish to establish a Limited Liability Company. Some of them want to establish a Limited Liability Company but have mediocre capital, even though they are already aware of the importance of establishing a Limited Liability Company which is a legal entity.

Then finally the Government made it easier for these conditions, as, in the previous explanation, the Government issued a new regulation stating that the amount of authorized capital for the establishment of a Limited Liability Company depends on the agreement of the founder. This has also been stated in Government Regulation Number 29 of 2016 concerning Changes in the authorized capital of Limited Liability Companies. Even so, this capital requirement only applies to small and medium enterprises.

2) Determine the Business Domicile

After the capital has been determined, it is time to determine the domicile of the business. This is to obtain a Company Domicile Certificate. However, some of the entrepreneurs also collided with insufficient funds to rent office space. Because there is a Regional Regulation for the Special Capital Region of Jakarta Number 1 of 2014 concerning Detailed Spatial Planning and Zoning Regulations. Even though this Company Domicile Certificate is very important to obtain a Taxpayer Identification Number, Company Registration Certificate, Trade Business License, or other business permits. Therefore, the solution that can be taken is to use a Virtual Office.

Virtual Office is a more economical option for businesses who wish to domicile in Jakarta. The requirements for domicile are indeed different in each region. If you are in Tangerang and Bogor, you can use your house as your business domicile to a certain extent. Whereas in Depok you have to use a building and a building permit, not a house. It is not uncommon for the Nuisance Law to ask for additional requirements

3) Determine the Business Field accordance with the Indonesian Standard Industrial Classification

Indonesian Standard Industrial Classification is a classification in determining the type of business which will be used to view the code of the business field, and later this business field code will be contained in the Trading Business License and also the Company Registration Certificate. The local government has made it easier for business people in this regard. The government makes this simple form of the Indonesian Standard Business Field Classification Code to be used as a reference in managing business licenses in the transported area.

4) Creating an Organizing Employment Social Security for Limited Liability Companies Creating an Organizing Employment Social Security for Limited Liability Companies. In managing the Employment Social Security Administering Body can do it online. This of course can save more time and faster than having to take care of it Offline. This Manpower Social Security Administering Body will be one of the requirements in processing other licenses, such as a Company Domicile Certificate.

5) Making Director's Taxpayer Identification Number and Corporate Taxpayer Identification Number

Menghadapi Era Global. Jurnal Rechtsvinding Media Pembinaan Hukum Nasional, 1(2): 188. 
To create a Limited Liability Company, you must also take care of a Taxpayer Identification Number, either for directors or companies. The Taxpayer Identification Number owned by the Director of a Limited Liability Company must already be in the latest format, 2015, which is that there is a Family Identification Number of the Director's Identity Card on his Personal Taxpayer Identification Number Card. Likewise, there is an address listed on the Taxpayer Identification Number. Besides, the Director of a Limited Liability Company concerned should not have tax arrears.

6) Making a Trading Business Permit and Company Registration Certificate

To make these two licenses, now it is even easier. Currently, you can apply for a trading business permit and a company registration certificate online. With only one login and filling out the online form, you can get this trading business license and company registration certificate at once. The procedure above can also be assisted by a notary. Therefore, administrative constraints are no longer a problem if each subdistrict has a business consulting service post which is a collaboration with related agencies, so that it is very helpful for the community to find information.

\subsection{Obstacle Factor Implementation of Government Policies to Minimum Capital Elimination for the Establishment of a Legal Entity}

Legal use consciously to change society is called social engineering by law. The steps taken in social engineering are systematic, starting from the identification of the problem to the solution, namely: Identifying the problem being faced as well as possible, including knowing carefully the people who want to be the target; Understand the values that exist in society because of the pluralistic conditions of society. At this stage, it is determined which sector value to choose, Make a hypothesis and choose which one is suitable to be used; Following the implementation of the law and measuring its effects, Soerjono Soekanto revealed (intended change or planned change) the changes that were planned and desired were intended as changes that were wanted and planned by the community members who acted as pioneers. In a complex society where the bureaucracy plays an important role in social action, inevitably it must have a legal basis for its validity. In this case, the law can be a powerful tool for bringing about social change, although indirectly. This also applies to government regulations made to regulate society.

Advancing a system, of course, cannot easily be carried out without an inhibiting factor for the implementation of the system. This also applies to efforts to develop a system for business activity units in Palu. Previously it was explained that in the law enforcement process, there are factors that influence and have the meaning of the implementation of laws/regulations so that the positive and negative impacts lie in the contents of these factors. According to Soerjono Soekanto, there are five of these factors, namely:

1) Its Law;

2) Law Enforcement;

3) Facilities and infrastructure;

4) Society; and

5) Culture.

Several questions were asked by researchers to obtain information related to what were the obstacles so that the enactment of Government Regulation Number 29 of 2016 is still not implemented effectively and efficiently. Some of these inhibiting factors include as follows: 
1) Lack of Information on Government Regulation Number 29 of 2016 concerning Changes in the Authorized Capital for the Establishment of Limited Liability Companies

There is no doubt that this Regulation only took effect in 2016 so that it is only one year since its entry into force. As one of the new regulations, then indeed, continuous socialization must always be carried out. The socialization is not only carried out by the regulators, but also by all parties who have a significant role and contribution, such as the central government, local governments, notaries, business associations, and even academics, especially in the social, economic, and legal fields. The need for a predictable law is deemed essential for a country where a large proportion of its people enter into economic relations beyond the traditional social environment. Aspects of justice, such as equal treatment and standard government behavior patterns, are needed to maintain market mechanisms and prevent excessive bureaucracy. ${ }^{12}$

Researchers ask questions in the form of do you know that to establish a Limited Liability Company, the government has issued Government Regulation Number 29 of 2016 concerning Changes to the Authorized Capital of Limited Liability Companies, in which the authorized capital is Rp. 50.000 .000 as a condition for the establishment of a Limited Liability Company has been removed, in other words, the establishment of a Limited Liability Company no longer requires an authorized capital as one of the conditions.

The facts show that the number of MSME who have received information about changes to the basic capital regulation of limited liability companies is 4 out of 44 micro, small and medium entrepreneurs who became respondents. As many as 40 respondents admitted that they were completely unaware of the change in the authorized capital for the establishment of a Limited Liability Company. Most of the respondents still considered that when applying for the establishment of a Limited Liability Company it was obligatory to provide funds as authorized capital of Rp. 50.000.000. Meanwhile, 4 respondents have known about these changes from their friends and family.

If presented, $91 \%$ (ninety-one percent) of the respondents did not know about the change in the authorized capital for the establishment of a Limited Liability Company. This presentation shows a very significant value to the ignorance of citizens in terms of improving their business.

2) Constraints on Requirements for the Establishment of a Limited Liability Company The part of the question about the reason the respondent does not want to develop their micro, small and medium businesses into a Limited Liability Company is:

a. Due to large capital constraints for the establishment of a Limited Liability Company.

b. Due to administrative system constraints, which are quite difficult.

The two problems mentioned above are the dominant reasons given by the respondents, given that they previously knew that apart from working capital, authorized capital must be prepared for the establishment of the largest company of Rp. 50.000.000, whereas many of the respondents thought that if that amount of money was used as working capital, it would certainly be of great help to production. However, about this capital, the government has issued a very pro-business policy, namely removing the requirement for authorized capital.

${ }^{12}$ L. J. Theberge. (1989). Law and Economic Development. N.Y.U.J. INT'L L. \& POL, p. 232. 
Respondents also said that the administrative system constraints were quite difficult because of the high costs incurred in establishing a Limited Liability Company. However, due to a lack of information, even micro, small and medium business entrepreneurs do not know that the government through Article 2 paragraph (2) and the attachment of Minister of Justice and Human Rights Regulation Number 3 of 2017 has provided policies that are considered to make it easier for business actors, especially micro, small and medium businesses to establish Limited Liability Companies. Regarding notary fees, the imposition of a notary legal service fee for the establishment of a Limited Liability Company for MSME is determined based on the following matters:

a. MSME, which has an authorized capital of at most Rp. 25.000.000, are subject to a fee of Rp. 1.000.000, with the following details:

\begin{tabular}{llll}
\hline No. & \multicolumn{1}{c}{ Type of Activity } & Type of Activity & \multicolumn{1}{c}{ Cost } \\
\hline 1 & $\begin{array}{l}\text { Approval for the Use of the Company } \\
\text { Name and Company ratification }\end{array}$ & Each Approval & Rp. 300.000 \\
\hline 2 & Cost of Notarial deed & Each Deed & Rp. 500.000 \\
\hline 3 & $\begin{array}{l}\text { Announcement fee in State Gazette of the } \\
\text { Republic of Indonesia and Addition to the } \\
\text { State Gazette of the Republic of Indonesia }\end{array}$ & Each & Rp. 200.000 \\
\end{tabular}

b. MSME that has a maximum authorized capital of Rp. 1.000 .000 .000 are subject to fees of Rp. 5.000.000, with the following details:

\begin{tabular}{llll}
\hline No & \multicolumn{1}{c}{ Type of Activity } & Type of Activity & Cost \\
\hline 1 & $\begin{array}{l}\text { Approval for the Use of the Company } \\
\text { Name and Company ratification }\end{array}$ & Each Approval & Rp. 600.000 \\
\hline 2 & Cost of Notarial deed & Each Deed & Rp. 4.000.000 \\
\hline 3 & $\begin{array}{l}\text { Announcement fee in State Gazette of the } \\
\text { Republic of Indonesia and Addition to the }\end{array}$ & Each & Establishment 400.000 \\
& $\begin{array}{l}\text { State Gazette of the Republic of } \\
\text { Indonesia. }\end{array}$ & & \\
\hline
\end{tabular}

\section{Conclusion}

Inhibiting factors for the implementation of government policies on the abolition of minimum capital for the establishment of legal entities is lack of information on Government Regulation Number 29 of 2016 concerning Changes in the Authorized Capital for the Establishment of Limited Liability Companies, constraints on the requirements for making limited liability companies due to large capital constraints for the establishment of a limited liability company or due to the administrative system constraints which are quite difficult, and the last is the orientation of individualist thought.

\section{References}

Books with an Author:

Budiono, H. (2015). Kumpulan Tulisan Hukum Perdata Bidang Kenotariatan. Bandung: Citra Aditya Bakti.

Partomo, T. S. dan Soejoedono, Abd. Rachman. (2002). Ekonomi Skala Kecil/Menengab \& Koperasi. Jakarta: Ghalia Indonesia.

Tambunan Tulus T. H.. (2002). Usaha Kecil dan Menengah Indonesia: Beberapa Isu Penting. Jakarta: Salemba Empat. 
Journal articles:

Bagijo, H. E. (2010). Sistem Pelayanan Perijinan Ho (Hinder Ordonnanntie) untuk Kegiatan Usaha Mikro, Kecil Dan Menengah (UMKM), Perspektif, 15(1): 21.

Budiyono, H. (2012). Arah Pengaturan Undang-undang Nomor 40 Tahun 2007 tentang Perseroan Terbatas dalam Menghadapi Era Global. Jurnal Rechtsvinding Media Pembinaan Hukum Nasional, 1(2): 188.

Theberge, L. J. (1989). Law and Economic Development. N.Y.U.J. INT'L L. \& POL, p. 232.

World Wide Web:

Fauzi. (2016). Sulteng Miliki 702719 UMKM. Available online from: http:/ / mwn.antarasulteng.com [Acessed February 3, 2020].

\section{Conflict of Interest Statement:}

The author declares that the research was conducted in the absence of any commercial or financial relationships that could be construed as a potential conflict of interest.

Copyright (C) 2021 ALJ. All rightsreserved. 